\title{
Study of Factors Affecting the Initial Public Offering (IPO) Price of the Shares on the Tehran Stock Exchange
}

\author{
Leila Bateni ${ }^{1} \&$ Farshid Asghari ${ }^{2}$ \\ ${ }^{1}$ Economics \& Management Department, Science and Research Branch, Islamic Azad University, Tehran, Iran \\ ${ }^{2}$ School of Economics, Payame-Noor University, Tehran, Iran \\ Correspondence: Leila Bateni, Economics \& Management Department, Islamic Azad University, Science and \\ Research Branch, Hesarak, Tehran, I. R. Iran. Tel: 98-919-355-8656. E-mail: batenileila@gmail.com
}

Received: June 27, 2014

doi:10.5430/rwe.v5n2p68
Accepted: July 23, 2014

Online Published: July 31, 2014

URL: http://dx.doi.org/10.5430/rwe.v5n2p68

\begin{abstract}
Price determined for a company's shares is true value of its property and opportunity for future development and growth. Nowadays Hundreds of companies enter stock exchange for the first time. Main question of this research is whether pricing the initial offering exchange on Tehran stock exchange is less than actual and what factors affect pricing of initial shares on stock exchange. For this purpose, 115 stock exchange companies from 2006 to 2012 were studied. Data gathered from these companies were analyzed with SPSS. Results indicated that only P/E variable has a significant relation with price changes on initial offerings and had highest impact on price of initial offerings.
\end{abstract}

Keywords: price of initial public offerings, stock exchange, price established on the subsidiary market

\section{Introduction}

Each day companies around the world enter stock exchange for the first time. Purpose of this participation is to support required investments to continue their activities and develop their operations. This matter makes price of shares in the initial offerings a very considerable subject, in other word; price determined for their shares indicates true properties value and grants future development and growth opportunities. However conducted researches by scholars around the world regarding initial stock offering show that stabilized price for shares in their first offering, lack proper utility and by buying these shares, allows investors to increase their short-term efficiency and achieve abnormal return. For liquidity development and spread, Tehran stock exchange and its operative mechanisms can achieve a great position in country's financial and economic structure.an introduction to economic development is success in supply and absorption of vast sources that failure to collect them cause deviation from production path and economic health reduction. If investing market in order to gain investment trust would be counted as policies efficient steps, and then surly it has took a step toward concentrating sparse investments and putting these investments to develop company's purposes thus leading to international production. Considering importance of investments in stock exchange and importance of pricing to attract investors and success of suppliers, this research studies shares initial offering pricing and factors affecting it.

Studies indicate 2 traits of initial offering pricing: first, shares on the initial offering are priced less than its actual value and second, aforementioned share in long-term have weaker performance comparing to other companies shares (Chi \& Padget, 2002, Boabang; 2007, Bundoo Aussenegg; 2002).

These traits cause scholars to pay considerable attention to pricing on initial offerings for the past two decades. Main subject of this research is to study factors that can affect shares pricings on the initial offerings. For example: investors' sensitivity, inflation, company's size, dealing share's volume on initial offering, number of buyers, current ratio and etc. hence this factors were studied.

\subsection{Initial Public Offerings}

The term initial public offerings that its vogue returns to thriving markets of 1990, means a company during its career intend to offer shares to public for the first time.

From the other point, initial public offering and entering stock exchange, includes limitations and costs whereas one of the major costs are data gathering according to stock exchange regulations, firm's audit cost and audited financial 
statements, underwriting cost and share issuance and some qualitative costs such as time that firms directive managers spend on affairs related to IPO, of course this costs are different depending on company's assurance volume and its marketing ability.

\subsubsection{Initial Public Offering Methods}

Initial Public offering can be initiated in many ways and highlighted methods of this affair are: registration, public offering as auction method, fixed price public offering and innovative internet methods. Utilizing each of these a method, regarding rules and regulations in different countries, varies but generally registration comparing to other methods, is more commonly used.

\subsubsection{Concepts regarding Share's Initial Offering}

Criegman (1999) believes company's first day transactions indicate share's future performance and he categorize shares to 4 types: 1.cold 2.cool 3.hot 4.very hot. Shares with 10-60\% efficiency on the first day are categorized as hot shares, these shares have highest offering requests thus some applicants can't afford this shares therefore demand shares in higher prices. Hot initial public offerings have high future performance (price increase) while abnormality return of cold offerings is equal or lower than zero and its future performance is weak (price reduction). Very hot offering is when share's initial return is more than $60 \%$ and its future performance will be serious. According many conducted researches on different countries, underpricing and price drop in long-term or long-term performance phenomenon have occurred. We discuss each phenomenon hereunder:

\subsubsection{Long-term Performance of Shares Initial Offering}

In long term, price performance of initial share offering comparing to other companies, is weak. Economical firms face many issues and uncertainties when entering stock exchanges thus, all this factors lead to the point that initial public offerings process- in their point of view- is a hazardous process.

\subsubsection{Short-term Return of Initial Share Offerings}

Experimental evidences indicate that investors, who buy shares in the first day of offering and sell it after a short period, receive an incredible return. In financial literature, short-term returns of shares initial offerings are attributed to underpricing (Allen, F. \& Faulhaber, G. R. 1989).

\section{Underpricing}

Underpricing means publishing company on the first day, offers its shares very lower than its true value leading to massive return gain for buyers.

\subsubsection{Theories regarding Less than Actual Offering}

Scholars proposed different reasons for underpricing. These reasons are in form of traditional theories from incommensurability of information to innovative theories such as behavioral, formed and proposed theories.in the following we discuss most important theories:

a. incommensurability of information

1) Asymmetric information between informed investors and not informed investors.

2) Asymmetric information between publishing companies and investment banks.

3) Asymmetric information between publishing companies and investors.

Based on these theories, underpricing of shares in initial public offering is due to asymmetric information between suppliers and share buyers (Akerlof, 1970). Winner's curse theory upon which, buyers are interested to offer prices higher than intrinsic value of stocks offered (Rock, 1986). According to "signaling theory", underpricing is the publisher act to indicate its share's value to the market (Allen \& Faulhaber, 1989).

b. Theories based on Institutional considerations

These theories attribute underpricing to legal responsibilities of share's suppliers. Sponsors' Risk aversion theory (Tinic, 1988), monopoly of finance institutions theory and supplying organization's conservatism theory are part of this category.

c. theories based on behavioral considerations

These theories discuss rationalization of investor's assumptions which is basis of classic financial knowledge and consider underpricing of shares in initial public offering due to Promiscuity of stock market which is based on 
investor's irrational behavior. (Welch, 1992) temporal interests and trends theory and investors' overreaction theory are among theories based on behavioral considerations.

\section{Methodology}

Current research method is survey, correlative, elevated and comparative. Part of this research is survey.to explains correlation, multi regression and Pierson statistical torque correlation method and for comparison, $\mathrm{T}$ test was used. All this tests and statistical applications were performed by utilizing SPSS.

Statistical society includes companies accepted by Tehran stock exchange from 2006 to 2012.sample count includes 115 accepted companies in 27 fields of industry. To determine sample volume, screening method was used.

Research information and data are gathered in 4 parts. First part includes information about history of share initial offering pricing and its fluctuations to answer the question of these research that whether pricings are less than actual or more than actual and to calculate price deviation.in Second part information related to investor overreaction, in third part; financial information from company's Financial Statements were gathered. Also In fourth part inflation rate was estimated using commodity price indicators that are released by central bank.

\subsection{Research Variables}

Number of first days: first days are days that shares on initial offering receive abnormal return before first price reduction.

Number of second days: are days that shares on the initial offering after reaching its highest value, reduced in a decreasing trend until it reaches the stabilized price on the second market.

Price deviation (MP): is the difference between stabilized price in second market (AP) and issuance price (IP) that due to lack of price offer by share's supplier, offered price (OP) is considered in calculations.28 day

Stabilized price in the second market (AP): share initial offering price reaches stabilized price in second market when it lacks price fluctuations of first stage. In this research, estimated time to reach price to equilibrium price is considered 328 day (almost a year) from the day of offer and equilibrium price is defined as the average share price on last five day of this period.(days 323-328)

Investors' overreaction (OR): is defined as investors interactions in time of receiving financial news in a way that they consider these news more than it weights and its roles on their investment decision making more than its actual share.

Offered price (OP): is the buyers offered price that first deal is made based on it and is accepted by supplier.

Other variables are: inflation rate, industry type, current rate, debt rate, fixed asset turnover rate, pure growth rate, and volume average of equations in first stage, volume average of equations in second stage, highest price of initially offered share till reaching stabilized price in the second market, ownership structure, EPS, and P/E ratio.

\section{Discussion and Results}

First hypothesis: Numbers of first day have a significance difference in different industries

Table 1. T test result relating to firs hypothesis

\begin{tabular}{lllll}
\hline variable & average & $\mathrm{t}$ & $\mathrm{df}$ & sig \\
\hline First stage days & 15.4 & 6.75 & 114 & .000 \\
\hline
\end{tabular}

Based on this test, on average, different industries after 15.4 from first day of offer experience first price reduction by second market. Highest and lowest abundance of first stage days are observed in automobile industry and part manufacturing plant. Tests results prove significant difference of first stage days between different industries.

In this hypothesis difference of first stage days between different industries were studied. This hypothesis results prove significance difference between different industries. This feature is higher in automobile industry and part manufacturing plant.

Second hypothesis: number of first days has significance difference based on inflation rate

Table 2. T test results related to second hypothesis

\begin{tabular}{lllll}
\hline variable & average & $\mathrm{t}$ & $\mathrm{df}$ & sig \\
\hline First stage days & 17.3 & 3.75 & 114 & .000 \\
\hline
\end{tabular}


Based on this test, on average, different industries after 17.3 from first day of offer experience first price reduction by second market. Highest and lowest abundance of first stage days are observed in different industries. Tests results prove significant difference of first stage days between different industries.

In this hypothesis effect of inflation on number of first days was studied. This hypothesis results prove that there's no significant relation between inflation rate and number of first days.

Third hypothesis: there's a significance relation between price deviation and investor sensitivity variables

Scholar in this hypothesis calculates investor sensitivity variables and defines deal volume in first offer, number of buyers in initial offer, inflation rate, $\mathrm{P} / \mathrm{E}$ ratio an current ratio, debt, shareholders salary return, pure growth value and to study this hypothesis used multiple regression test.

Result of regression test: after eliminating variables with no significance relation with dependent variable price deviation, only approved relationship was between independent variable $\mathrm{P} / \mathrm{E}$ ratio and price deviation

Table 3. Regression test synchronous results for price deviation scores predicament

\begin{tabular}{llllllll}
\hline variable & & $\begin{array}{l}\mathrm{R} \text { multiple correlation } \\
\text { coefficient }\end{array}$ & $\mathrm{R}$ & square & $\mathrm{F}$ & STATISTIC & Sig \\
\hline $\begin{array}{l}\text { Price deviation } \\
\text { sensitivity variables }\end{array}$ & and & investor & 0.264 & 0.345 & 5.493 & .000 \\
\hline
\end{tabular}

In this hypothesis investor sensitivity variables were defined and for studying them, multiple regression test was used. After elimination of variables irrelevant to the dependent variable price deviation, the only relationship of an independent variables with price deviation was confirmed.

Results indicate that among all investor sensitivity variables there's a significant and positive relation ( $\mathrm{R}=0.264)$ ONLY between P/E ratio and price deviation. Also it can be preserved that $34 \%$ of price deviation changes can be estimated with $\mathrm{P} / \mathrm{E}$ ratio.

Fourth hypothesis: investor's overreaction has significant difference in different industries

Table 4. T test result related to fourth hypothesis

\begin{tabular}{lllll}
\hline & Sum square & df & $\begin{array}{l}\text { F difference } \\
\text { indicator }\end{array}$ & Sig \\
variable & & 114 & 0.022 & .518 \\
\hline $\begin{array}{l}\text { Investor over } \\
\text { reaction in different } \\
\text { industries }\end{array}$ & 528,730 & & & \\
\hline
\end{tabular}

According to intergroup test ANOVA with significance level of 0.518 , difference of investor overreaction in different industries is not confirmed.

Fifth hypothesis: investor overreaction has significant difference based on inflation rate

Table 5. T test results related to fifth hypothesis

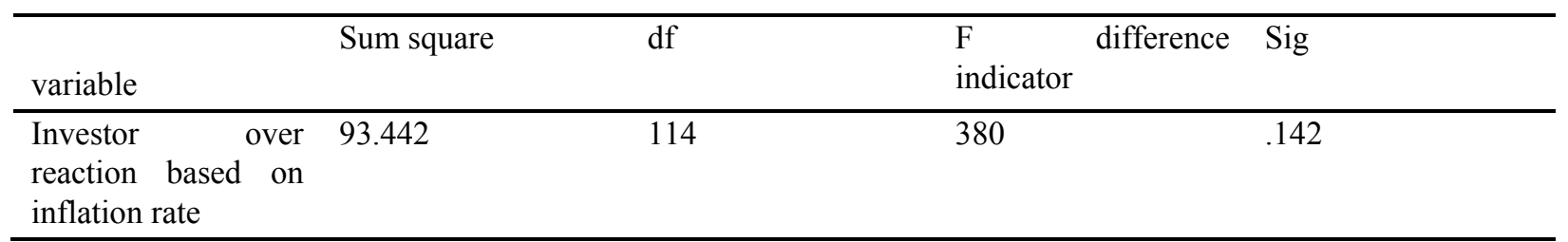

According to intergroup test ANOVA with significance level of 0.142 , results indicate that investor overreaction is not a function of inflation rate, thus this variable doesn't have significant difference in different rates of inflation.

Sixth Hypothesis: there's a significant relation between investor overreaction and investor sensitivity variables

Table 6. Regression synchronous result for investor reaction scores' prediction

\begin{tabular}{lllll}
\hline variables & $\begin{array}{l}\text { R multiple correlation } \\
\text { coefficient }\end{array}$ & R square & F statistic & Sig \\
\hline $\begin{array}{l}\text { Price deviation and investor sensitivity } \\
\text { variables }\end{array}$ & 0.184 & 0.445 & 3.218 & 0.642 \\
\hline
\end{tabular}


To evaluate this hypothesis multiple regression test was used wherein investor reaction was considered a dependent variable and investor sensitivity variables were considered independent.

According to test's results, sixth theory that proposed relation between investor and sensitivity variables was not confirmed. In fact investor reaction which is represented in investment market and grants public accessibility and indicators such as inflation has no correlation.

Seventh hypothesis: there's a relation between economic, accounting variables and stabilized price in secondary market

Table 7. Seventh hypothesis Spearman coefficient

\begin{tabular}{|c|c|c|c|}
\hline variable & $\begin{array}{l}\text { Spearman statistical } \\
\text { value }\end{array}$ & P-Value & total \\
\hline $\begin{array}{l}\text { Economic, accounting variables and stabilized price in } \\
\text { secondary market }\end{array}$ & 0.716 & 0.000 & 115 \\
\hline
\end{tabular}

In table above relationship between economic/accounting variables and stabilized price in secondary market was evaluated according to comments of 115 samples. As it can be seen according to Spearman statistical value (0/716) and level of error below 0.01 ( $\mathrm{P}$-Value $<0.01$ ) we can concede that relation between above variables is significant in 0.99 confidence level. In other word hypothesis zero is denied and scholar hypothesis is approved. Thus, there's a significant relation between economic/accounting variables and stabilized price in secondary market. Also Spearman's correlation coefficient between two variables indicates that intensity of their relationship is strong and positive and direct.

Eighth hypothesis: number of days that price is stabilized is not zero

After a period of price intense fluctuations and offer and order changes in secondary market, price will be stabilized

\begin{tabular}{lllll}
\hline Variable & amount & average & Freedom degree & Sig \\
\hline Days that price will be stabilized & 115 & 287 & 115 & 0.00 \\
\hline
\end{tabular}

According to data gathered and their analysis which are shown, in short, in table above after share's initial offering, it takes 287 days for prices to be stabilized in secondary market. This amount comparing with other country is high.

Ninth hypothesis: price deviation, in initial offering is higher than zero

\begin{tabular}{lllll}
\hline variable & amount & average & variance & Standard deviation \\
\hline Price deviation & 115 & 12.31 & 78.37 & 7.15 \\
\hline
\end{tabular}

Price deviation average is equal 12.31 which shows that stabilized price in secondary market is $13 \%$ higher than offered price. To be more precise, share initial offering pricing is less than actual. Thus it can be concluded that in markets when initial offering is represented with price lower than actual, not only spreader will have a successful offering, but also investors and investment market actives can receive return higher than their desired return.

\section{Conclusion}

Present research studies pricing of initial stock offering in Tehran's stock exchange in time range of 1385-1391 and research primary question is whether initial stocks offered in Tehran stock exchange are valued less than actual or not, and what factors affect pricing of initial stock offering . Also responding to questions like "what is time period of reaching stabilized price in secondary market?"' is one of many purposes of this research. Research discoveries are as follows:

1) Initially offered stocks face increased price in average of 15 days after first transaction.in studying number of first days in different industries, significant difference in number of first days of different industries was observed. Despite expecting that in cement industries, petroleum products and drug manufacturing, number of first day is higher than other industries, this feature was orderly highest in automobile, part manufacturing and activities relevant, machinery and installations industries. Other conclusion does not confirm relation between number of first day and inflation rate. In fact price increase after first offering does not have a significant relationship with inflation rate.

2) In Iran's stock exchange average days that price is stabilized is 287 days. This number is a very high amount comparing to other countries, one of its reasons is investment market efficiency, the more market is efficient, information transfer is don with more clarity thus, shares initially offered will be transacted with price close to 
its actual price and it takes less time for initially offered shares to reach stabilized price in market. From the other hand price stabilization is result of investment banks that by stabilizing prices, decrease price fluctuations especially if the closed price is close to offering price stated for transactions. Therefore one of the major reasons of non-stabilization of prices in investment market of Iran is gaps due to absence of financing institutions and investment banks.

3) Studying price deviation with average of 14.3 emphasize that stabilized price in secondary, market is $14.3 \%$ higher than offering price of the initially offered shares' first transaction.

4) Studying price deviation in different industries show that highest price deviation belongs to automobile industries and parts manufacturing plants where automobile industry has the highest abnormal return. On the other hand, a significance relation between inflation rate and price deviation was not confirmed. Among financial and economic variables, only relationship between $\mathrm{P} / \mathrm{E}$ ratio and price deviation was confirmed.

\section{References}

Akerlof, G. (1970). The market for "Lemons": quality uncertainty and market mechanism. Quarterly Journal of Economics, 84(3), 488-500. http://dx.doi.org/10.2307/1879431

Aleen, F., \& Faulhaber, G. R. (1989). Signaling by underpricing in the IPO market. Journal of Financial Economics, 23(1), 303-323. http://dx.doi.org/10.1016/0304-405X(89)90060-3

Aussenegg, W. (2000). Privatization versus private sector initial public offering in Poland. Multinational Finance Journal, 4(1\&2), 69-99. Retrieved from http://ssrn.com/abstract=931684

Boabang, F. (2003). The IPOs of Canadian firms via installment receipts: The opening performance and implications for the short-run efficiency of the Canadian market. Canadian Journal of Administrative Sciences, 20(3), 224-233. http://dx.doi.org/10.1111/j.1936-4490.2003.tb00313.x

Bundoo, S. K. (2007). An Analysis of IPOS Underpricing in Mauritius. African Journal of Accounting, Economics, Finance and Banking Research, 1(1), 1-12. Retrieved from http://ssrn.com/abstract=1534144

Chi, J., \& Padget, C. (2002). Short-run underpricing and its characteristics in Chinese IPO markets. The university of Readings: ISMA discussion papers in finance 2001-2012, 2-38. http://dx.doi.org/10.1016/j.ribaf.2004.10.004

Chong, A., \& Riano, A. (2006). Political Environment and Privatization Prices. Washington D.C: Inter-American Development Bank. http://dx.doi.org/10.1007/s11127-011-9788-9

Dempere, J. M. (2008). SELF-UNDERWRITTEN IPOS. Journal of Global Business and Technology, 4(1), 1-18.

Rock, K. (1986). Why new issues are underpriced. Journal of Financial Economics, 15(1-2), 187-212. http://dx.doi.org/10.1016/0304-405X(86)90054-1

Schindele, I., \& Perotti, E. C. (2002). Pricing Initial Public Offerings in Premature Capital Markets: The Case of Hungary. London: University of Amsterdam. http://dx.doi.org/10. 2139/ssrn.363921

Stevenson, S. (2006). The abnormal performance of UK utility privatizations. Studies in Economics and Finance, 23(3). 164-184. http://dx.doi.org/10.1108/10867370610711020

Suchard, J., \& Singh, M. (2007). Determinants of pricing of privatization IPOs in the UK and Australia. International Journal of Business, 12(3), 361-384. Retrieved from http://ssrn.com/abstract=1141360

Tinic, S. M. (1988). Anatomy of initial public offerings of common stock. Journal of Finance, 43(4), 789-822. http://dx.doi.org/10.1111/j.1540-6261.1988.tb02606.x

Vickers, J., \& Yarrow, G. (1988). Privatization: An Economic Analysis. Cambridge: MIT Press. http://dx.doi.org/10.1016/0167-2681(90)90047-H

Vieira, C., \& Serra, A. P. (2006). Abnormal returns in privatization public offerings: the case of Portuguese Firms. Notas Economicas, 22, 1-35. Retrieved from http://ssrn.com/abstract=692027

Welch I. (1989). Seasoned offerings, imitation costs, and the underpricing of initial public offerings. Journal of Finance, 44(2), 421-449. http://dx.doi.org/10.1111/j.1540-6261.1989.tb05064.x 